\title{
Simulating the mid-Pliocene climate with the MIROC general circulation model: experimental design and initial results
}

\author{
W.-L. Chan ${ }^{1}$, A. Abe-Ouchi ${ }^{1,2}$, and R. Ohgaito ${ }^{2}$ \\ ${ }^{1}$ Atmosphere and Ocean Research Institute, University of Tokyo, Kashiwa, Japan \\ ${ }^{2}$ Research Institute for Global Change, Japan Agency for Marine-Earth Science and Technology, Yokohama, Japan
}

Received: 28 July 2011 - Published in Geosci. Model Dev. Discuss.: 19 August 2011

Revised: 9 November 2011 - Accepted: 16 November 2011 - Published: 29 November 2011

\begin{abstract}
Recently, PlioMIP (Pliocene Model Intercomparison Project) was established to assess the ability of various climate models to simulate the mid-Pliocene warm period (mPWP), 3.3-3.0 million years ago. We use MIROC4m, a fully coupled atmosphere-ocean general circulation model (AOGCM), and its atmospheric component alone to simulate the mPWP, utilizing up-to-date data sets designated in PlioMIP as boundary conditions and adhering to the protocols outlined. In this paper, a brief description of the model is given, followed by an explanation of the experimental design and implementation of the boundary conditions, such as topography and sea surface temperature. Initial results show increases of approximately $10^{\circ} \mathrm{C}$ in the zonal mean surface air temperature at high latitudes accompanied by a decrease in the equator-to-pole temperature gradient. Temperatures in the tropical regions increase more in the AOGCM. However, warming of the AOGCM sea surface in parts of the northern North Atlantic Ocean and Nordic Seas is less than that suggested by proxy data. An investigation of the model-data discrepancies and further model intercomparison studies can lead to a better understanding of the mid-Pliocene climate and of its role in assessing future climate change.
\end{abstract}

\section{Introduction}

The mid-Pliocene corresponds to the most recent period in the earth's history during which global increases in temperatures reached magnitudes similar to those predicted for the late 21 st century by many general circulation models (Jansen et al., 2007). As such, the mid-Pliocene has been of immense interest in recent years, not only to the paleoclimate community, but also to climate modellers assessing climate sensitiv-

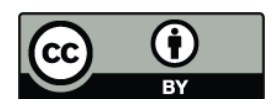

Correspondence to: W.-L. Chan (wlchan@aori.u-tokyo.ac.jp) ity. To gain more confidence in simulations of future climate change, it may be useful to test models on alternative scenarios, namely those of the past. This will also allow an assessment of the consistency of past climate changes with current theories. The mid-Pliocene presents an ideal opportunity as it includes several potential palaeoclimate targets for reducing uncertainties in future projections (Schmidt, 2010). In this respect, it offers several advantages over other previous warm periods, in that conditions were similar to those of present day in many ways. Atmospheric $\mathrm{CO}_{2}$ concentration is estimated to be about $380 \mathrm{ppm}$ with intervals of peak warmth possibly reaching $45 \mathrm{ppm}$ higher (Raymo et al., 1996). The geographical configuration of the land masses and ocean basins, as well as the global ocean circulation, were close to those of present day. Marine and continental fauna were essentially modern and fossil proxies are in abundance. Moreover, many mid-Pliocene species still exist today and thus, temperature proxies based on modern calibrations are feasible (Robinson et al., 2008a). As such, an increasing number of proxy data have become available. For example, Robinson et al. (2008b) have derived multiproxy temperature estimates from faunal assemblages, foraminifer $\mathrm{Mg} / \mathrm{Ca}$ and alkenone unsaturation indices. Others have used proxies to confirm estimates of past $\mathrm{CO}_{2}$ concentrations. Pagani et al. (2010) analysed alkenones at several Ocean Drilling Program sites to reconstruct early and middle Pliocene $\mathrm{CO}_{2}$ concentrations and to evaluate the Earth-system climate sensitivity. A multiproxy approach (Seki et al., 2010) using a combination of sedimentary alkenones and the $\delta^{11} \mathrm{~B}$ of foraminifera has yielded similar estimates while increasing the level of confidence in the accuracy of such records.

Simulations of the mid-Pliocene climate started in earnest with the GISS AGCM (Chandler et al., 1994) which used data from the United States Geological Survey's (USGS) Pliocene Research Interpretation and Synoptic Mapping (PRISM) Group as boundary conditions. Since then, simulations have been performed with other models, ranging

Published by Copernicus Publications on behalf of the European Geosciences Union. 
from the UKMO AGCM/AOGCM (Haywood et al., 2000; Haywood and Valdes, 2004) to the IAP AGCM (Jiang et al., 2005), amongst others. With the possible exception of HADAM3, GCMAM3 and CAM3-CLM (e.g., Haywood et al., 2009), little headway has been made in methodical comparisons between model results. In addition, the use of AOGCMs for the mid-Pliocene simulations has so far been limited, in contrast to those of the Last Glacial Maximum and mid-Holocene, as documented by the Palaeoclimate Modelling Intercomparison Project (PMIP), now in its third phase (see http://pmip3.lsce.ipsl.fr for further details).

In 2008, the Pliocene Model Intercomparison Project (PlioMIP) was initiated as part of the more inclusive PMIP whose aim is to encourage a systematic study of state of the art climate models by evaluating their capability to reproduce past climate states, vastly different to that of today, and by carrying out model-model and model-data comparisons. PlioMIP focuses on simulations of the mid-Pliocene warm period, defined as the interval between 3.3 and 3.0 Ma. The first stage of PlioMIP consists of two experiments which are run with an AGCM and a fully coupled AOGCM, and utilise up-to-date data sets from PRISM. The experimental designs for the AGCM and AOGCM are laid out concisely in Haywood et al. (2010, 2011), with differences only in the treatment of the oceans. As one participating model of the project, the Model for Interdisciplinary Research on Climate (MIROC) is used to simulate the mid-Pliocene climate, adhering to the guidelines set out in PlioMIP. In this paper, we give a description of MIROC and explain how the boundary conditions are applied. This is followed by a discussion on some initial results.

\section{Model description}

The coupled atmosphere-ocean general circulation model (AOGCM) used in our experiments is MIROC4m, where $\mathrm{m}$ stands for mid-resolution. This is an updated model of the previous mid-resolution version of MIROC3.2, the AOGCM developed at the institutes CCSR/NIES/FRCGC and used in the Intergovernmental Panel on Climate Change 4th Assessment Report, IPCC AR4 (Meehl et al., 2007), although the dynamics and physics remain unchanged. Further details on the model can be found in K-1 model developers (2004). We give a brief description of the main features of the model below. For the atmospheric general circulation model (AGCM), we use the atmospheric component of the MIROC4m AOGCM with prescribed sea surface temperatures (SSTs).

The AOGCM consists of five components, namely atmosphere, land, river, sea ice and ocean. Air-sea exchange is first realised between the atmosphere and sea ice components before interaction with the ocean component, although at icefree grids air-sea flux is passed directly to the ocean compo- nent without modification. No flux adjustments are applied in the model.

\subsection{Atmospheric model}

The AGCM (CCSR/NIES/FRCGC AGCM5.7b) is based on that described in Numaguti (1997). Medium resolution is employed, with the horizontal resolution set to T42, corresponding roughly to a grid size of $2.8^{\circ}$. There are 20 vertical $\sigma$ levels and the height of the model top is approximately $30 \mathrm{~km}$. Surface height is generated from the USGS GTOPO30 dataset. Basically, a leap-frog scheme is employed for time discretization. Adiabatic advective processes are treated in a dynamics time step and other processes in a physics time step.

Prognostic variables are updated three times in each physics time step. The first update occurs after a cumulus convection parameterization scheme which is a modified form of that devised by Arakawa and Schubert (1974). The second occurs after a large scale condensation scheme based on that of Le Treut and Li (1991). The third occurs after the remaining physical processes. For subgrid vertical fluxes of prognostic variables, the level 2 scheme of the turbulence closure model by Mellor and Yamada (1982) is used.

A radiative transfer scheme (Nakajima et al., 2000) based on the two-stream discrete ordinate and k-distribution methods is employed. Optical parameters for water cloud, ice cloud, soil dust, black carbon, organic carbon, sulphate and sea salt are also included. Classification of aerosols is based on SPRINTARS (Spectral Radiation-Transport Model for Aerosol Species) - see Takemura et al. (2000). However, parameters are calculated off-line and are accessed by the AGCM through a table.

\subsection{Land-surface and river routing models}

The land-surface model employed is MATSIRO (Minimal Advanced Treatments of Surface Interaction and Runoff), details of which can be found in Takata et al. (2003). The horizontal resolution matches that of the atmospheric model. The vertical structure consists of a canopy layer, 5 soil layers and up to 3 snow layers. Energy and water exchange between the land surface and the atmosphere are represented as is runoff flux to a river routing model. Prognostic variables include canopy temperature, canopy water content, snow amount, snow temperature, soil temperature and soil moisture content. Calculation of the snow albedo is based upon Wiscombe and Warren (1980). Most of the boundary conditions are generated from the ISLSCP Initiative I data set (National Aeronautics and Space Administration, 1996), while land-cover type is derived from USGS GLCC (Global Land Cover Characterization). Soil albedos are specified for visible and near infrared wavelength bands.

The river routing scheme used to model the transport of runoff water to the ocean is based on Miller et al. (1994). A 
globally constant river flow speed of $0.3 \mathrm{~ms}^{-1}$ is assumed for simplicity. The time step is set to $3 \mathrm{~h}$.

\subsection{Ocean model}

The ocean general circulation model (OGCM) corresponds to version 3.4 of the CCSR Ocean Component Model (COCO). Refer to Hasumi (2000) for more details. Primitive equations are solved on a sphere where the Boussinesq and hydrostatic approximations are employed. The zonal resolution is fixed at $1.40625^{\circ}$, that is, 256 equally spaced grid points. In the meridional direction, there are 192 grid points whose resolution is approximately $0.56^{\circ}$ between latitudes $8^{\circ} \mathrm{N}$ and $8^{\circ} \mathrm{S}, 1.4^{\circ}$ north of $65^{\circ} \mathrm{N}$ and south of $65^{\circ} \mathrm{S}$, and varies smoothly elsewhere. There are 43 vertical levels, the top 8 of which are in $\sigma$-coordinates. Prognostic variables are arranged horizontally on the Arakawa B staggered grid system. The barotropic mode equations are integrated in time steps of $30 \mathrm{~s}$ and others in steps of $20 \mathrm{~min}$. A combination of the leap-frog and Euler-backward schemes are used for the integration of the prognostic equations, although only the latter is used for the barotropic mode equations.

The model bathymetry for present day is calculated from ETOPO5 (NOAA, 1998), a 5-min resolution bathymetry data set. A 2 grid gap represents the Bering Strait so that there is only one velocity grid point. Certain areas of water are represented as isolated basins, such as the Hudson Bay and the Mediterranean Sea. At the straits which connect these basins to adjacent seas, tracers and sea surface elevation are artificially exchanged by a 2-way linear damping.

A brief description of the physical parameterization schemes follows. The model applies a simple vertical adjustment, whereby a statically unstable water column is homogenized instantaneously. Vertical mixing of momentum and tracers uses diffusion and viscosity coefficients as calculated by Noh and Kim (1999) whose parameterization scheme is based on level 2.5 turbulence closure of Mellor and Yamada (1982). The turbulent Prandtl number is modified to include dependency on the turbulent Richardson number. A background viscosity coefficient of $1.0 \times 10^{-4} \mathrm{~m}^{2} \mathrm{~s}^{-1}$ is applied to all levels, whereas the background coefficient varies from $0.1 \times 10^{-4} \mathrm{~m}^{2} \mathrm{~s}^{-1}$ at the ocean top to $3.0 \times 10^{-4} \mathrm{~m}^{2} \mathrm{~s}^{-1}$ at the deepest level. For lateral mixing of momentum, Smagorinsky's biharmonic visocity (Smagorinksy, 1963) is used with a coefficient value of $3.0 \times 10^{4} \mathrm{~cm}^{2} \mathrm{~s}^{-1}$, although, at latitudes north of $60^{\circ} \mathrm{N}$ and south of $60^{\circ} \mathrm{S}$, this value reduces to zero linearly with increasing latitude. To parameterize tracer lateral mixing, harmonic horizontal diffusion, harmonic isopycnal diffusion and harmonic horizontal diffusion of isopycnal layer thickness are applied; coefficients are set to $1.0 \times 10^{2} \mathrm{~m}^{2} \mathrm{~s}^{-1}, 1.0 \times 10^{3} \mathrm{~m}^{2} \mathrm{~s}^{-1}$ and $7.0 \times 10^{2} \mathrm{~m}^{2} \mathrm{~s}^{-1}$, respectively. The bottom boundary parameterization of Nakano and Suginohara (2002) is used to represent downslope flow of dense water. The bottom layer, of thickness $100 \mathrm{~m}$, is applied only at latitudes north of $49^{\circ} \mathrm{N}$ and south of $54^{\circ} \mathrm{S}$.

\subsection{Sea ice model}

In the sea ice model, sea ice concentration, mean sea ice thickness and horizontal velocity components are predicted. The first two vary with thermodynamic growth, advection and mechanical deformation of ice floes. Zero-layer thermodynamics (Semtner, 1976) is assumed and only latent heat of sea ice melt is considered in the heat budget. Sea ice exists only when the temperature at the top level of the ocean model is at freezing point. If the temperature of the seawater underneath exceeds freezing point, sea ice amount is reduced until the temperature reduces to freezing point. The salinity of sea ice is fixed at $5 \mathrm{psu}$ and meltwater runs off into the ocean directly. The momentum equation for sea ice consists of an advection term, a Coriolis term, an acceleration term due to the slope of the sea surface, an internal stress term and an external forcing term derived from wind stress and iceocean drag. Lead formation is parameterized by imposing a maximum value for the sea ice concentration.

The sea ice model also assumes the role of the coupled model's air-sea interface, calculating heat, freshwater and momentum exchange. The albedo of bare ice surfaces is set to 0.5 , while that of snow-covered surfaces is 0.85 for temperatures below $15^{\circ} \mathrm{C}, 0.65$ for $0{ }^{\circ} \mathrm{C}$, and varies linearly in between.

\section{Experimental design}

The experimental design for the mid-Pliocene modelling follows that presented in Haywood et al. $(2010,2011)$. A set of boundary conditions, derived from data sets of the USGS PRISM group, is specified in PlioMIP. This set includes land/sea mask, topography, ice sheets, vegetation and SST specifically for models in which the user can change the land configuration to match that of the mid-Pliocene (referred to as "preferred" boundary conditions), although an alternative set is also given for other models. The former set is used with MIROC. The design for the AGCM experiment will be described first. All the PRISM3D boundary conditions (with the exception of prescribed SST and sea ice extent) used in the MIROC AGCM are also used in the AOGCM. A summary can be found in Table 1. For comparative purposes, we used results from control experiments, obtained previously with the same AGCM and AOGCM. In all experiments, insolation, greenhouse gases and orbital parameters are kept at pre-industrial $1850 \mathrm{AD}$ levels, as in Ohgaito and AbeOuchi (2007). However, atmospheric $\mathrm{CO}_{2}$ concentration is increased to $405 \mathrm{ppm}$ for the mid-Pliocene case. 
Table 1. Summary of the experimental design, parameters and boundary conditions imposed. The names of PRISM3D data files used are enclosed in brackets. Those applied as an anomaly to control experiment data sets are marked with an asterisk.

\begin{tabular}{|c|c|c|c|c|}
\hline \multirow[b]{2}{*}{ PlioMIP experiment no. } & \multicolumn{2}{|c|}{ Control run } & \multicolumn{2}{|c|}{ Mid-Pliocene run } \\
\hline & - & - & 1 & 2 \\
\hline Model & AGCM & AOGCM & AGCM & AOGCM \\
\hline Total integration length & $235 \mathrm{yr}$ & $3800 \mathrm{yr}$ & $50 \mathrm{yr}$ & $1400 \mathrm{yr}$ \\
\hline Years used for analysis & Last $60 \mathrm{yr}$ & Last $100 \mathrm{yr}$ & Last $10 \mathrm{yr}$ & Last $100 \mathrm{yr}$ \\
\hline Ocean temperature & $\begin{array}{l}\text { MIROC } \\
\text { pre-industrial } \\
\text { climatological } \\
\text { SST }\end{array}$ & Dynamic & $\begin{array}{l}\text { PRISM3D } \\
(\text { PRISM3_SST_v1.1*) }\end{array}$ & $\begin{array}{l}\text { Dynamic } \\
\text { For initial state: } \\
\text { PRISM3D } \\
\text { (Global_dot_v2.0*) }\end{array}$ \\
\hline Land/sea mask & \multicolumn{2}{|l|}{ MIROC modern } & \multicolumn{2}{|c|}{ PRISM3D (land_fraction_v1.1*) } \\
\hline Topography & \multicolumn{2}{|l|}{ MIROC modern } & \multicolumn{2}{|l|}{ PRISM3D (topo_v1.1*) } \\
\hline Ice sheets and vegetation & \multicolumn{2}{|l|}{ MIROC modern } & \multicolumn{2}{|c|}{ PRISM3D (biome_veg_v1.3) } \\
\hline Atm. $\mathrm{CO}_{2}$ concentration & \multicolumn{2}{|l|}{$285 \mathrm{ppm}$} & \multicolumn{2}{|l|}{$405 \mathrm{ppm}$} \\
\hline Other greenhouse gases & \multicolumn{4}{|c|}{$\mathrm{CH}_{4}: 863 \mathrm{ppb}, \mathrm{N}_{2} \mathrm{O}: 279 \mathrm{ppb}, \mathrm{CFC}:$ none, $\mathrm{O}_{3}: 1850$ AD level } \\
\hline Solar constant & \multicolumn{4}{|l|}{$1366 \mathrm{Wm}^{-2}$} \\
\hline Orbital parameters & \multicolumn{4}{|c|}{ eccentricity $=0.016724$, obliquity $=23.446^{\circ}$, angular precession $=102.04^{\circ}$} \\
\hline
\end{tabular}

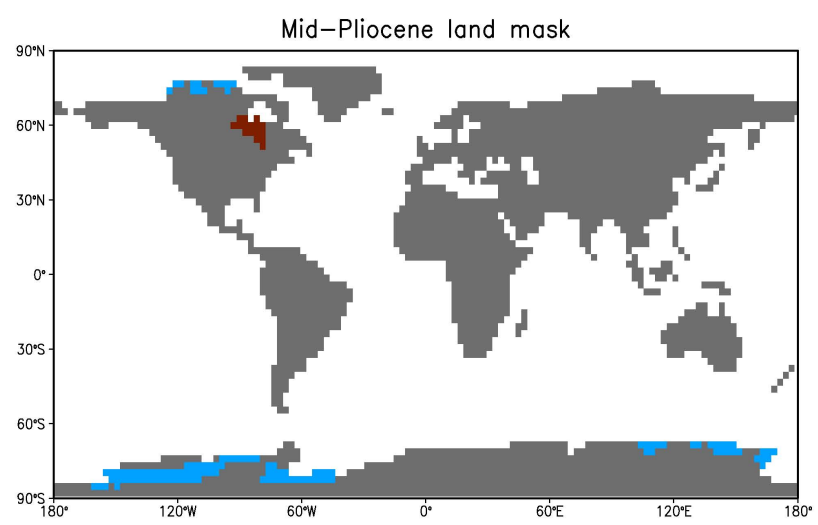

Fig. 1. Land sea mask used for the mid-Pliocene. The blue grid cells represent areas which are ocean in the mid-Pliocene but are land in present day. Conversely, the brown grid cells represent areas which are land in the mid-Pliocene but are ocean (namely, the Hudson Bay) in present day.

\subsection{Land/sea mask and land elevation}

The PRISM3D fractional land/sea mask and its modern day equivalent are interpolated from their original $2^{\circ} \times 2^{\circ}$ grid to the $2.8^{\circ} \times 2.8^{\circ}$ grid employed in the MIROC AGCM. The difference between the mid-Pliocene and modern day val-

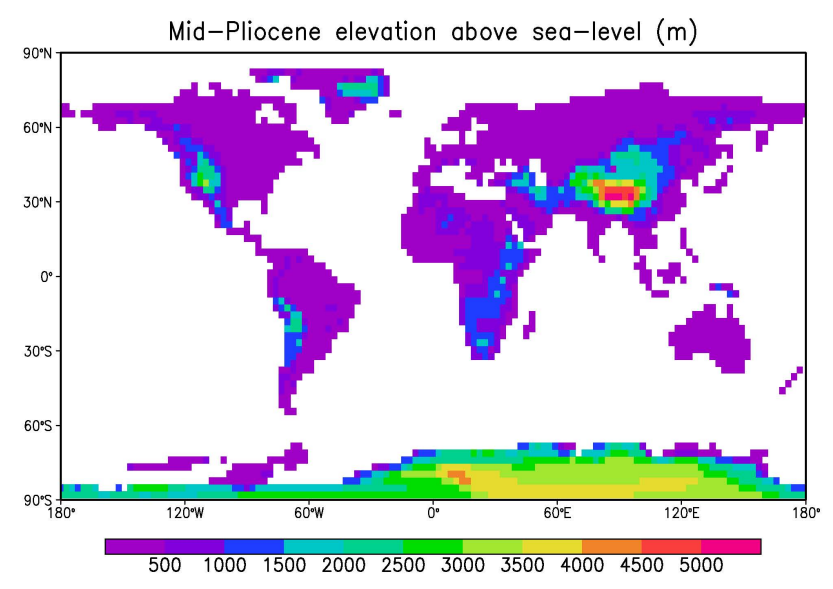

Fig. 2. Surface height above sea-level in the mid-Pliocene experiment.

ues are then calculated and added to the MIROC land/sea mask. Regions where the resulting fractional land/sea mask is less than 0.7 are ignored and those where the largest, most prominent changes occur fall into three categories: coastal areas around Antarctica and in parts of northern Canada which were formerly land, and the Hudson Bay, which is now mostly in-filled. The other regions where the land/sea mask has changed consist primarily of isolated grid cells or 

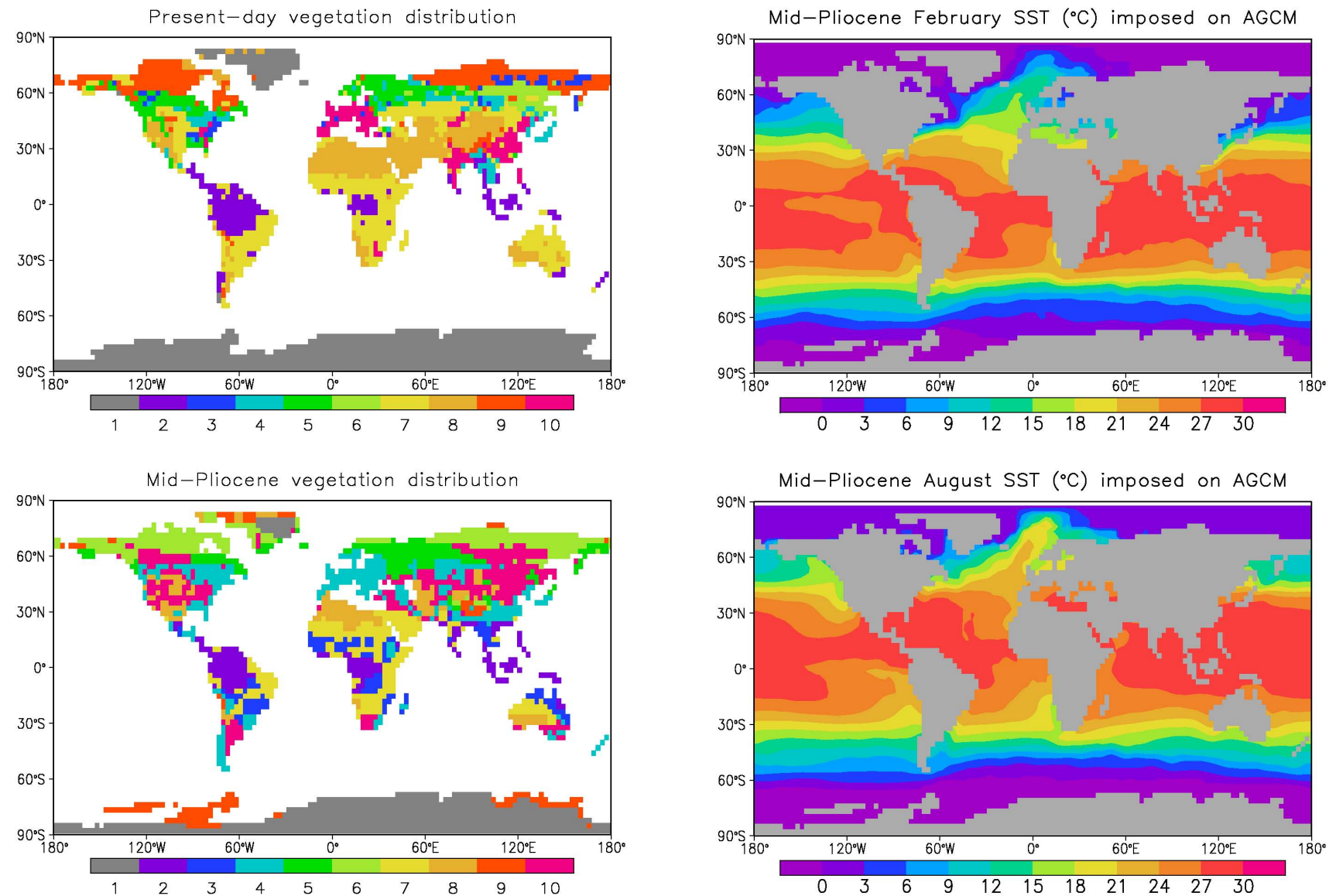

Fig. 3. Surface index denoting land vegetation in the present day (top figure) and in the mid-Pliocene (bottom figure). Key: (1) continental ice, (2) broadleaf evergreen forest, (3) broadleaf deciduous forest and woodland, (4) mixed coniferous, broadleaf deciduous forest and woodland, (5) coniferous forest and woodland, (6) high latitude deciduous forest and woodland, (7) wooded C4 grassland, (8) shrubs and bare ground, (9) tundra, (10) C3 grassland.

small clusters of cells. For simplicity, we decide to alter the three previously mentioned regions only, as shown in Fig. 1. Notice the absence of the West Antarctic ice sheet. Although a flat bathymetry with average depth of $500 \mathrm{~m}$ was recommended for this deglaciated region, numerical instability set in soon after the start of the time integration. Instead, we set the depth of the newly created bathymetry to that of the shallowest ocean grid points in the model, i.e. approximately $42 \mathrm{~m}$ (8th level). Ocean gateways, notably the closed Central American Seaway and the open Bering Strait, remain unchanged in all experiments.

Mid-Pliocene land elevations are derived from the topographic reconstruction of Sohl et al. (2009) whereas modern land elevations are re-gridded from the ETOPO1 Global Relief Model data (Amante and Eakins, 2008). Using these two data sets, topography is implemented as an anomaly. In

Fig. 4. Mid-Pliocene sea surface temperature imposed on the AGCM during February and August.

other words, we calculate the difference between the given mid-Pliocene topography and that of modern day. This difference, interpolated onto the relevant grid, is added to the modern day topography in the MIROC AGCM. Any ocean grid cells which appear in the resulting topographic data set are subsequently masked out, following Fig. 1 and elevation values which are negative in grid cells representing land are changed to sea-level. The final topography is shown in Fig. 2.

\subsection{Other boundary conditions for the land surface}

PRISM3D reconstruction of the distribution of mid-Pliocene vegetation and ice sheets, derived from Salzmann et al. (2008) and Hill et al. (2007) is incorporated into the model. The original data, on a $2^{\circ} \times 2^{\circ}$ grid, consist of a 28-type biome. Each surface grid cell in the MIROC AGCM is allocated a biome type as specified by the closest grid cell in the data set before conversion to MIROC vegetation type. The conversion scheme is detailed in Table 2 and the geographical distribution of land vegetation, including ice sheet 


\section{Sea ice mass per unit area $\left(\mathrm{kg} \mathrm{m}^{-2}\right)$ in AGCM}
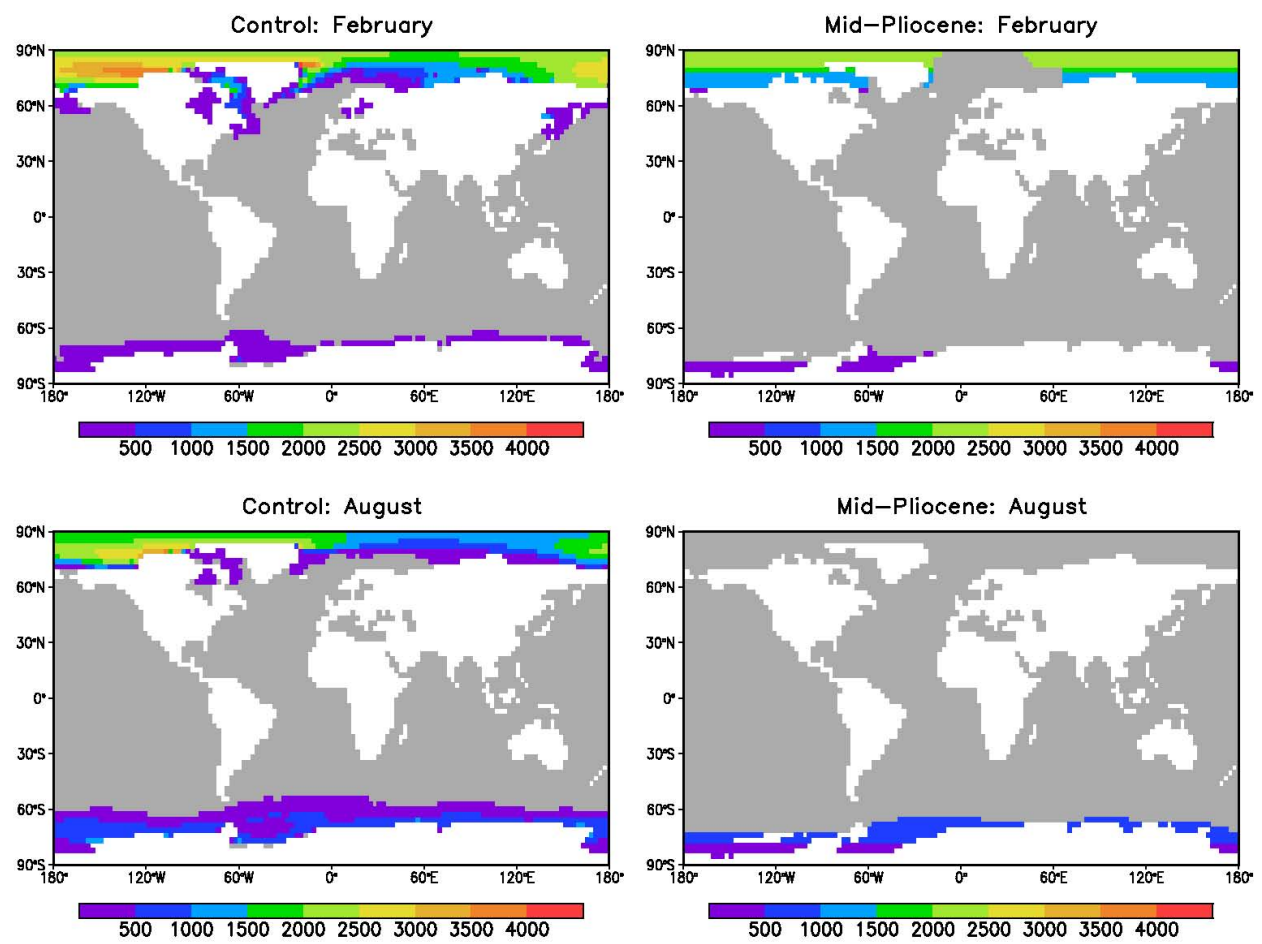

Fig. 5. Sea ice mass per unit area imposed on the AGCM during February and August for the control experiment (left side) and for the mid-Pliocene experiment (right side).

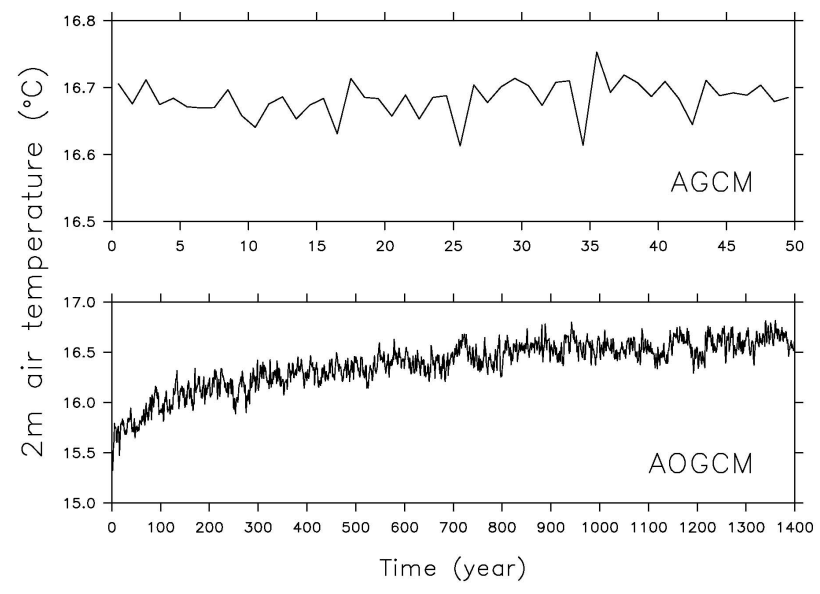

Fig. 6. Time series of the globally averaged value of $2 \mathrm{~m}$ air temperature for the AGCM and AOGCM.

extent, is displayed in Fig. 3. There are no mid-Pliocene data available for the leaf area index (LAI). Thus, we allocate a minimum and maximum LAI to each cell grid depending on

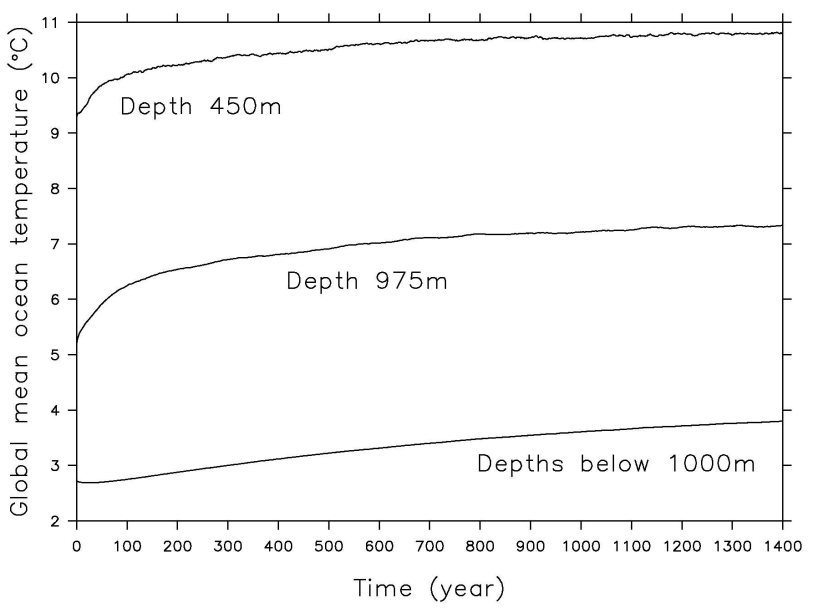

Fig. 7. Time series of the globally averaged value of the AOGCM ocean temperature at various depths.

its vegetation type (Table 3 ) and determine a new LAI with a simple dependency on the month and latitude by fitting a sine curve. Soil albedos for both visible and near infrared 
(a) Surf. air temp. (total)

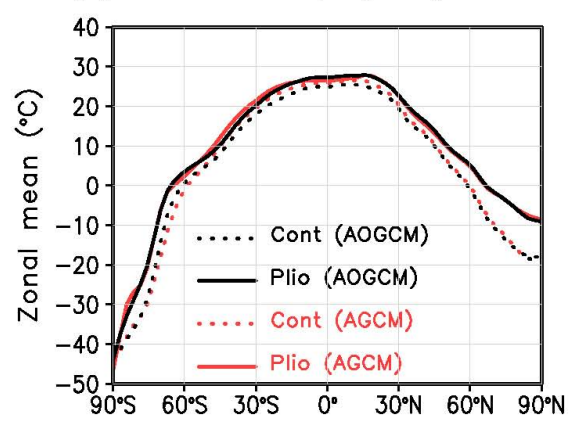

(b) Surf. air temp. (ocean)

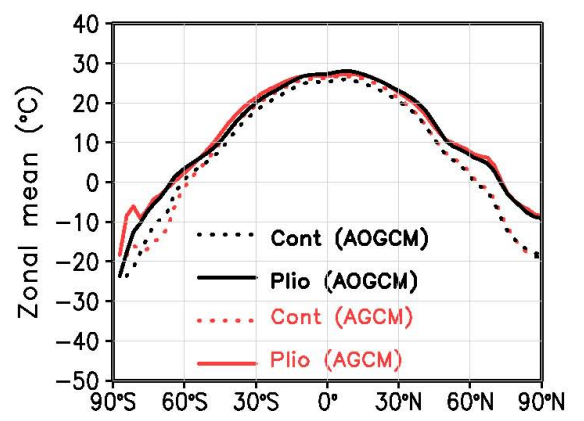

(c) Surf. air temp. (land)

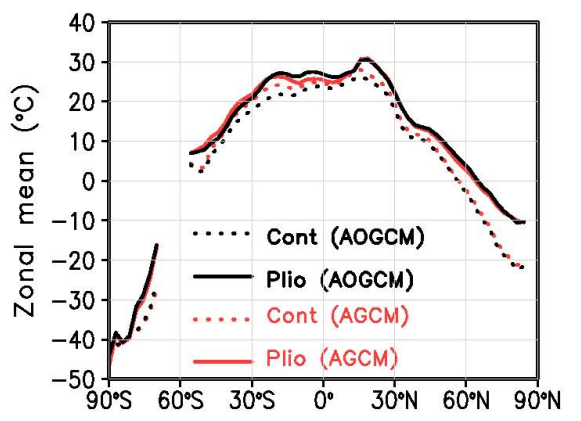

(d) Surf. air temp. diff. (total)

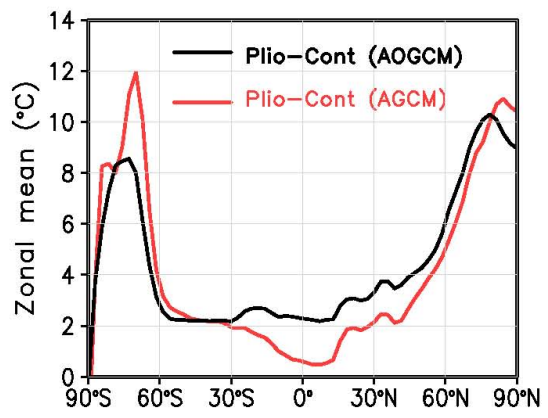

(e) Surf. air temp. diff. (ocean)

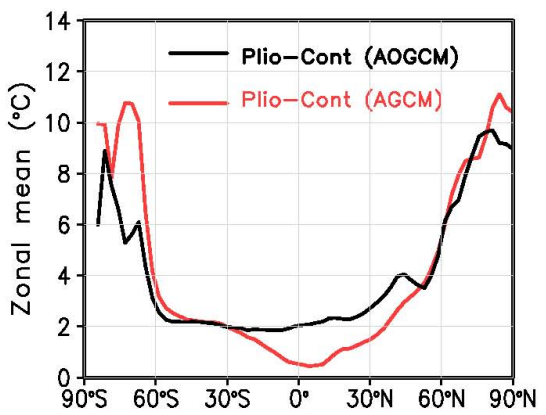

(f) Surf. air temp. diff. (land)

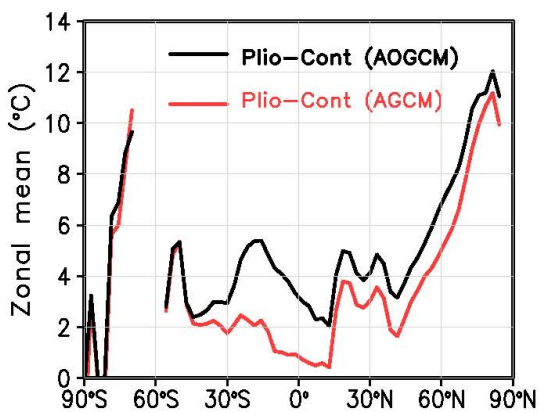

Fig. 8. Zonal mean surface air temperature $(\mathbf{a}, \mathbf{b}, \mathbf{c})$ for the control (dotted lines) and mid-Pliocene (solid lines) experiments, and their differences $(\mathbf{d}, \mathbf{e}, \mathbf{f})$. Values for the AGCM and AOGCM are denoted in red and black, respectively.

wavelength bands are modified according to the new vegetation distribution (Table 3).

Some minor changes are required in the river routing. New river routes, across the in-filled Hudson Bay for example, are created such that they follow the steepest gradient in the midPliocene topography. Soil texture is left largely unchanged. However, the in-filled Hudson Bay is replaced by medium soil texture, similar to that of some surrounding grid cells. Likewise, in regions of the Antarctic and Greenland where there are no ice sheets, soil texture is set to medium.

\subsection{Conditions for the ocean}

In the AGCM, SST data sets (Dowsett, 2007; Robinson et al., 2008b), provided by PRISM3D, are used to prescribe the SST for each month. As with topography, PRISM3D SST anomalies, calculated by subtracting modern SST values (Reynolds and Smith, 1995), are applied. That is, the difference between the Pliocene and modern day PRISM3D SST values are added to the MIROC values after interpolating onto the MIROC grid to create a new set of Pliocene SST, as shown in Fig. 4. Refer to Fig. 5 of Dowsett et al. (2009b) or Fig. 7 of Haywood et al. (2010) for maps of the PRISM3D SST anomalies. In the control AGCM experiment, preindustrial SSTs were previously prescribed. Applying an 


\section{AGCM: Surface Air Temperature $\left({ }^{\circ} \mathrm{C}\right)$}
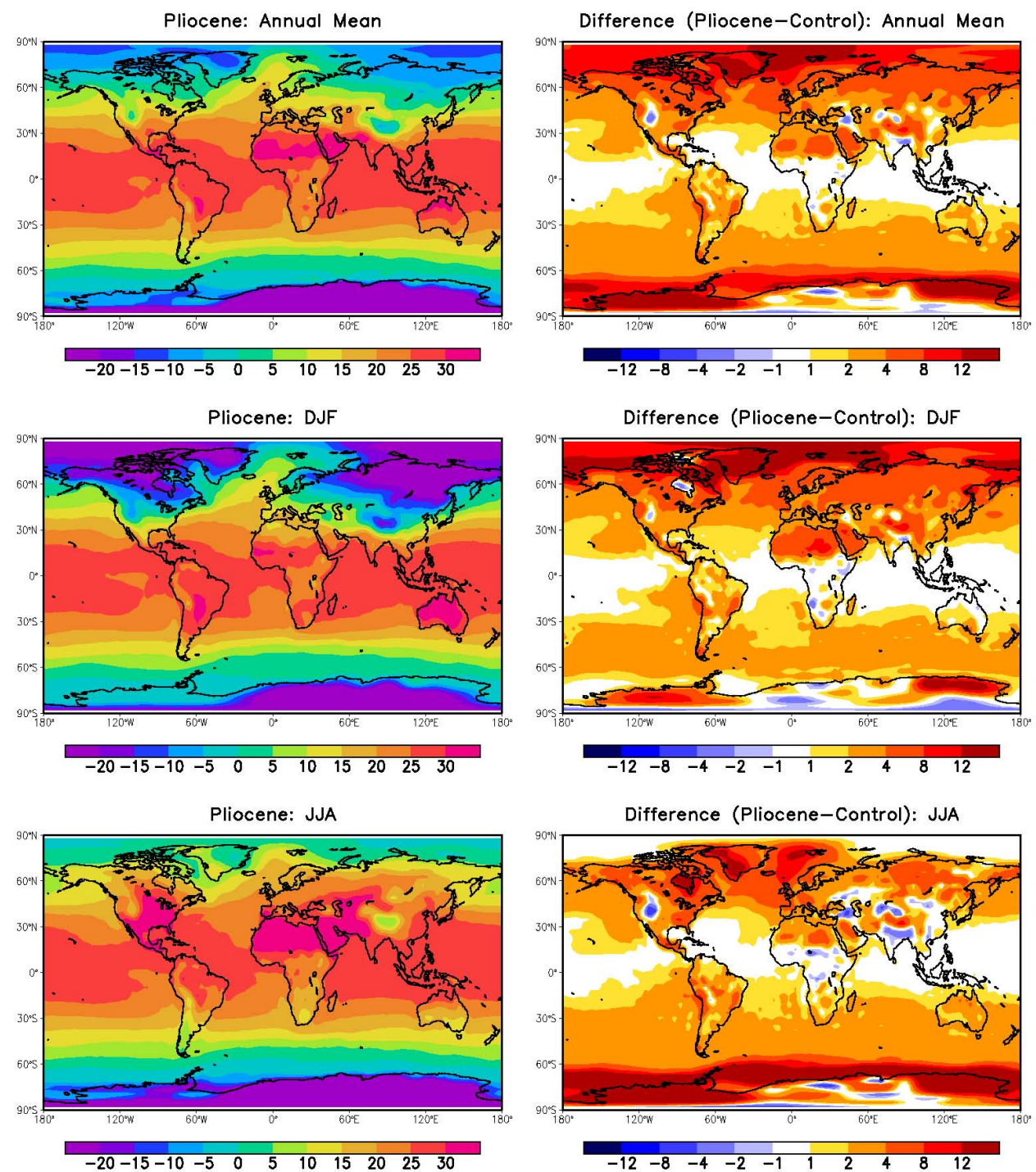

Fig. 9. AGCM mid-Pliocene surface air temperature averaged over the entire year, December-January-February and June-July-August (left side), and the differences between these values and those of the control experiment (right side).

anomaly based on modern day SST may raise some issues of consistency, more so in locations where the differences between pre-industrial and modern day SST are comparable to the SST anomaly being applied. We intend to rerun the control AGCM experiment prescribed with modern day SST in addition to the corresponding Pliocene experiment in the near future to examine the extent to which the atmospheric responses using these two sets of SST values differ from one another.

Sea ice extent is incorporated within this SST dataset and is represented at grid points where SST is $-1.8^{\circ} \mathrm{C}$. Monthly sea ice mass per unit area is prescribed for the AGCM and for the mid-Pliocene experiment, we assign our own particular values as follows. Zonal mean values in the control run are calculated across grids where there is sea ice. These zonal mean values are then assigned to grid points where SST is $-1.8^{\circ} \mathrm{C}$ in the mid-Pliocene run. Figure 5 shows the sea ice mass per unit area for the control and mid-Pliocene cases during February and August.

For the AOGCM, a 3-dimensional sea temperature data set (Dowsett, 2007; Robinson et al., 2008b; Dowsett et al., 2009a,b) for December is used to create the initial conditions for the mid-Pliocene ocean. This data set is specified in a horizontal grid of resolution $5^{\circ} \times 4^{\circ}$ and at the same 33 vertical 


\section{AOGCM: Surface Air Temperature $\left({ }^{\circ} \mathrm{C}\right)$}
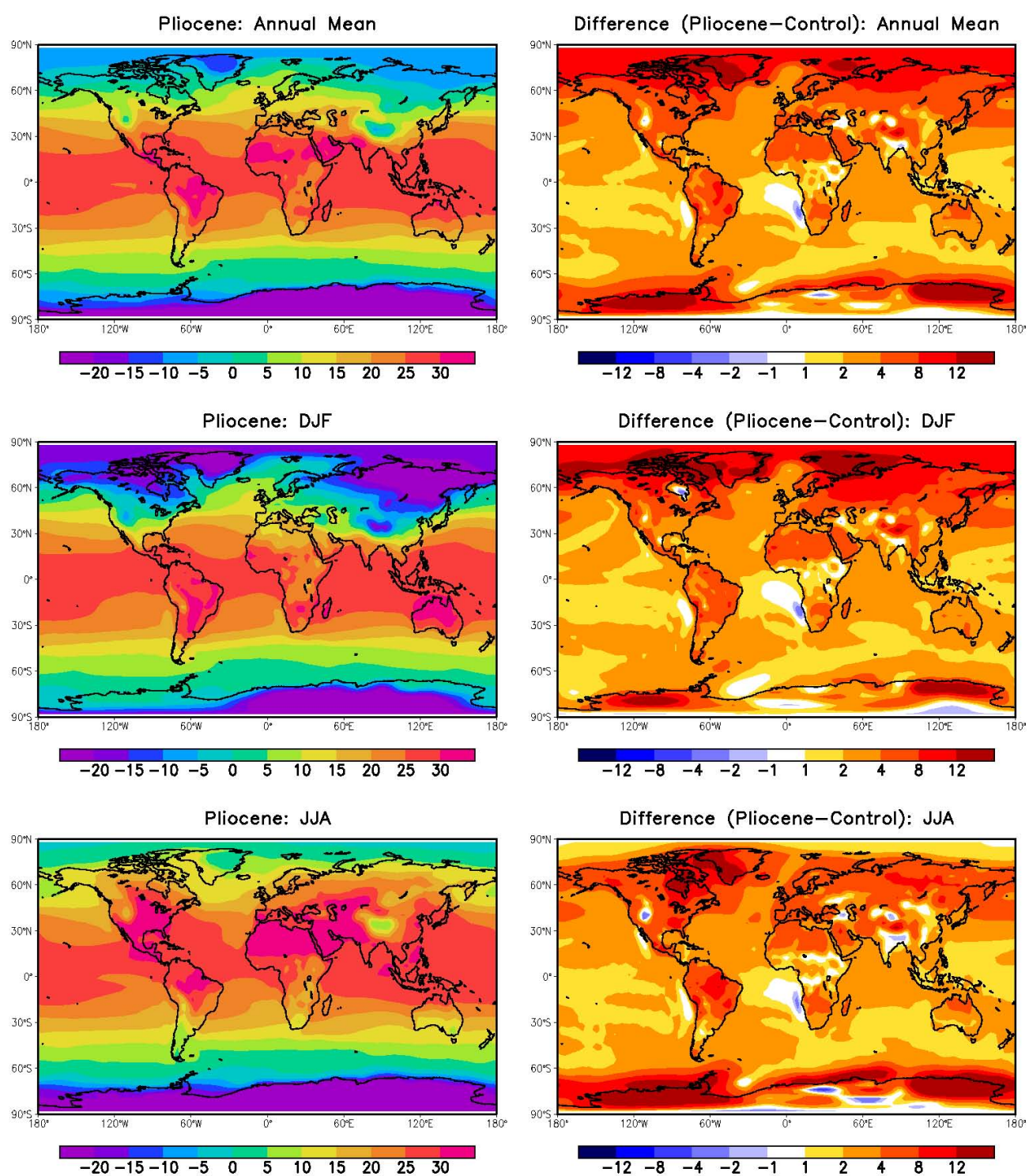

Fig. 10. AOGCM mid-Pliocene surface air temperature averaged over the entire year, December-January-February and June-July-August (left side), and the differences between these values and those of the control experiment (right side).

levels as those in LEVITUS94 (Levitus and Boyer, 1994). We calculate the difference between this data set and the accompanying LEVITUS94 data set which serves as the modern day values, interpolate the difference (Dowsett et al., 2009b, Fig. 7) onto the MIROC ocean grid and add the result to the MIROC sea temperature values of the control run to obtain the initial conditions. The initial condition of the sea salinity, like that of the atmosphere, is derived, without modification, from the end of the control run.

\subsection{Time integration}

The AGCM and AOGCM are integrated for $50 \mathrm{yr}$ and $1400 \mathrm{yr}$, respectively. For analysis, climatological means are calculated from the final $10 \mathrm{yr}$ and $100 \mathrm{yr}$, respectively. Replacing the $100 \mathrm{yr}$ averaging period for the AOGCM with a shorter $30 \mathrm{yr}$ period does not produce significantly different results. The time series of the globally averaged surface air temperature is shown for both models in Fig. 6. For the temperature to reach equilibrium, the AOGCM requires a 


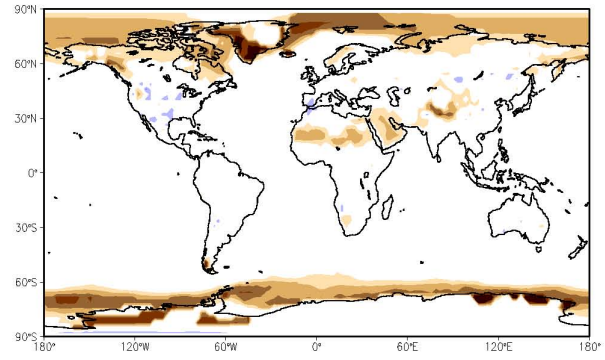

(a)

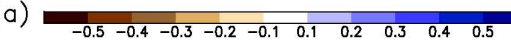

AGCM: Albedo diff. (Plio-Cont)
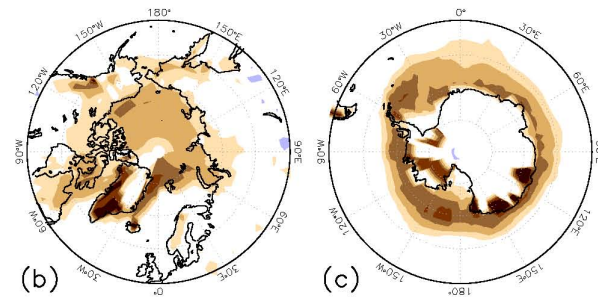

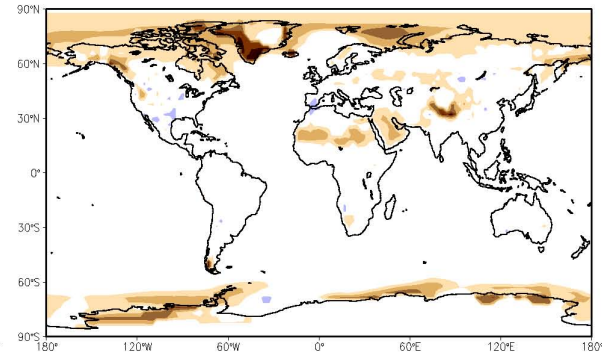

(d)

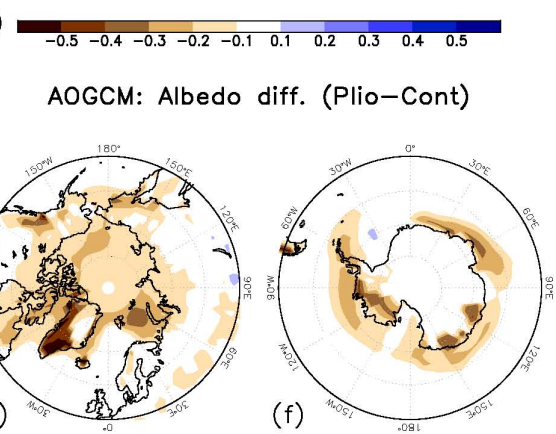

Fig. 11. Difference between the annual mean surface albedos in the mid-Pliocene and control experiments. AGCM results are shown on the left (a-c) and AOGCM results on the right (d-f). The polar regions are also shown at the bottom (b, $\mathbf{c}, \mathbf{e}, \mathbf{f})$.

spin up of approximately $1000 \mathrm{yr}$. Temperatures in the ocean component of the AOGCM (Fig. 7) still show small increasing tendencies, although these are limited to depths below $1000 \mathrm{~m}$.

\section{Results}

\subsection{Global and zonal mean values}

Selected global mean values are shown in Table 4. Surface air temperature increases more in the AOGCM, $3.5^{\circ} \mathrm{C}$ compared to $2.8^{\circ} \mathrm{C}$, although the resulting temperatures in both models are similar. The former compares favourably with values obtained from a number of other models: $3.6^{\circ} \mathrm{C}$ in the NCAR GENESIS AGCM (Sloan et al., 1996) and $3.3^{\circ} \mathrm{C}$ in the HadCM3 AOGCM (Lunt et al., 2010). Total precipitation also increases, despite a decrease in snowfall. The precipitation increase is nearly twice as large in the AOGCM.

The globally averaged absorbed shortwave radiation at the top of the atmosphere (TOA) increases by about $5 \mathrm{Wm}^{-2}$ in both models. The largest contributions are found in areas where the albedo has reduced: firstly, over northern Africa, the Arabian peninsula and central Asia where the deserts have either reduced in area or disappeared completely; secondly, over Greenland and parts of the Antarctic during their respective summers. Larger increases in the western Antarctic and over the British Isles and the Norwegian Sea account for the larger global increase in the AGCM value. The out- going longwave radiation at the TOA increases nearly twice as much in the AOGCM compared to the AGCM. Basically, the outgoing longwave radiation increases much more at low and mid-latitudes (where surface air temperature increases are greater in the AOGCM - see next section), especially over the Atlantic, Africa, southern Europe and South America. The local response can be completely opposite in the two models, for example over the Indian Ocean and Indonesia/northern Australia. The total outgoing radiation reduces by $2.87 \mathrm{Wm}^{-2}$ and $0.30 \mathrm{Wm}^{-2}$ in the AGCM and AOGCM, respectively.

Zonal mean values for the surface air temperature are displayed in Fig. 8. In both models, the temperature at high latitudes increases by approximately $10^{\circ} \mathrm{C}$. In general, the changes from the low- to high-latitudes are more extreme in the AGCM, leading to a greater reduction in the equatorto-pole temperature gradient. Temperature gains at low latitudes are smaller in the AGCM but there is a larger polar amplification due to the oceans. At low- to mid-latitudes, in contrast to the dip in the equatorial region of the AGCM, there is a rather uniform increase of $2^{\circ} \mathrm{C}$ from $55^{\circ} \mathrm{S}$ to $20^{\circ} \mathrm{N}$ in the AOGCM. This is the result of a more uniform increase over the oceans and a significantly large increase over South America (see next section).

\subsection{Surface air temperature}

Figure 9 shows the surface air temperature for the AGCM and the difference between the mid-Pliocene and control 
Table 2. Vegetation type in the PRISM3D data set and in MIROC, and the scheme used to convert the former to the latter for the mid-Pliocene experiments.

\begin{tabular}{|c|c|c|c|}
\hline & PRISM3D & & MIROC \\
\hline 1 & Tropical evergreen forest & \multirow[t]{2}{*}{2} & \multirow[t]{2}{*}{ Broadleaf evergreen forest } \\
\hline 2 & Tropical semi-deciduous forest & & \\
\hline 3 & Tropical deciduous forest/woodland & 3 & Broadleaf deciduous forest and woodland \\
\hline 4 & Temperate deciduous forest & \multirow[t]{3}{*}{4} & \multirow{3}{*}{$\begin{array}{l}\text { Mixed coniferous, broadleaf deciduous forest } \\
\text { and woodland }\end{array}$} \\
\hline 5 & Temperate conifer forest & & \\
\hline 6 & Warm-temperature mixed forest & & \\
\hline 7 & Cool mixed forest & \multirow[t]{3}{*}{5} & \multirow[t]{3}{*}{ Coniferous forest and woodland } \\
\hline 8 & Cool conifer forest & & \\
\hline 9 & Cold mixed forest & & \\
\hline 10 & Evergreen taiga/montane forest & \multirow[t]{2}{*}{6} & \multirow[t]{2}{*}{ High latitude deciduous forest and woodland } \\
\hline 11 & Deciduous taiga/montane forest & & \\
\hline 12 & Tropical savanna & \multirow[t]{2}{*}{7} & \multirow[t]{2}{*}{ Wooded C4 grassland } \\
\hline 13 & Tropical xerophytic shrubland & & \\
\hline 14 & Temperate xerophytic shrubland & 8 & Shrubs and bare ground \\
\hline 15 & Temperate sclerophyll woodland & \multirow[t]{6}{*}{10} & \multirow[t]{6}{*}{ C3 grassland } \\
\hline 16 & Temperate broadleaved savanna & & \\
\hline 17 & Open conifer woodland & & \\
\hline 18 & Boreal parkland & & \\
\hline 19 & Tropical grassland & & \\
\hline 20 & Temperate grassland & & \\
\hline 21 & Desert & 8 & Shrubs and bare ground \\
\hline 22 & Steppe tundra & \multirow[t]{5}{*}{9} & \multirow[t]{5}{*}{ Tundra } \\
\hline 23 & Shrub tundra & & \\
\hline 24 & Dwarf-shrub tundra & & \\
\hline 25 & Prostrate shrub tundra & & \\
\hline 26 & Cushion-forb, lichen, moss tundra & & \\
\hline 28 & Land-ice & 1 & Continental ice \\
\hline
\end{tabular}

experiments. Most, but not all, regions across the globe show an increase in temperature. As noted before, there is clearly a latitudinal dependence in this temperature increase, especially over the oceans. Little change is observed in the low- and mid-latitudes except over land masses such as South America, northern Africa and the Arabian peninsula. Conversely, large increases are seen at high-latitudes. In the most extreme cases, increases in excess of $25^{\circ} \mathrm{C}$ are seen over eastern Greenland, the Nordic Seas and the Barents Sea during boreal winters and $25^{\circ} \mathrm{C}$ over parts of the Antarctic during austral winters. During their respective summers, temperature increases in these regions can still reach $10^{\circ} \mathrm{C}$. Thus, although overall temperatures have increased at high latitudes, they are generally less variable throughout the year. There are noticeably some areas where the temperature has reduced. These are confined to land - western North America including the Rocky Mountains, eastern Peru, central Africa, parts of the Middle East, northeast India, central Asia and parts of the eastern Antarctic where the Pliocene elevation is higher than that of present day in the model. The calculated mid-Pliocene elevation is lower than that for modern day in the coastal areas west of the Andes but higher in the eastern part of the Central Andes (located in Bolivia). There is a similar east-west divide in the elevation anomalies of western North America. These anomalies with opposite signs are reflected in increased temperatures (for example, in northern Chile where the increase is much higher than the zonally averaged value) and in decreased temperatures. Cooling in parts of Africa is also found by others (e.g. Chandler et al., 1994; Haywood et al., 2000) and is consistent with pollen data from Ethiopia (Bonnefille et al., 2004).

In the AOGCM, surface air temperature (Fig. 10) increases over most areas, as in the AGCM, and the largest increases are concentrated in Greenland and Antarctica. There are 
Table 3. Maximum and minimum values of the leaf area index (LAI) and soil albedo values for visible and near infrared wavelength bands corresponding to each vegetation type in the mid-Pliocene experiments.

\begin{tabular}{llllll}
\hline & Vegetation type & $\begin{array}{l}\text { Max. } \\
\text { LAI }\end{array}$ & $\begin{array}{l}\text { Min. } \\
\text { LAI }\end{array}$ & $\begin{array}{l}\text { Albedo } \\
\text { (Visible) }\end{array}$ & $\begin{array}{l}\text { Albedo } \\
\text { (NIR) }\end{array}$ \\
\hline 1 & Continental ice & 0.000 & 0.000 & 0.100 & 0.150 \\
\hline 2 & Broadleaf evergreen forest & 4.490 & 4.490 & 0.110 & 0.215 \\
\hline 3 & Broadleaf deciduous forest and woodland & 3.900 & 0.429 & 0.108 & 0.210 \\
\hline 4 & $\begin{array}{l}\text { Mixed coniferous, broadleaf deciduous forest } \\
\text { and woodland }\end{array}$ & 4.190 & 0.870 & 0.108 & 0.198 \\
\hline 5 & Coniferous forest and woodland & 4.210 & 0.956 & 0.111 & 0.212 \\
\hline 6 & High latitude deciduous forest and woodland & 4.930 & 0.244 & 0.110 & 0.222 \\
\hline 7 & Wooded C4 grassland & 1.838 & 0.723 & 0.117 & 0.204 \\
\hline 8 & Shrubs and bare ground & 0.287 & 0.192 & 0.248 & 0.279 \\
\hline 9 & Tundra & 2.110 & 0.125 & 0.110 & 0.214 \\
\hline 10 & C3 grassland & 2.190 & 0.799 & 0.101 & 0.155 \\
\hline
\end{tabular}

Table 4. Global mean annual values of surface air temperature, sea surface temperature, sea surface salinity, total precipitation, rainfall, snowfall and radiation fluxes at the top of the atmosphere (TOA). The differences between the mid-Pliocene and control runs are given in columns 4 and 6.

\begin{tabular}{llrrrr}
\hline Variable & Units & $\begin{array}{r}\text { AGCM } \\
\text { Pliocene }\end{array}$ & $\begin{array}{r}\text { AGCM } \\
\text { Plio-Cont }\end{array}$ & $\begin{array}{r}\text { AOGCM } \\
\text { Pliocene }\end{array}$ & $\begin{array}{r}\text { AOGCM } \\
\text { Plio-Cont }\end{array}$ \\
\hline Surface air temperature & ${ }^{\circ} \mathrm{C}$ & 16.68 & 2.75 & 16.63 & 3.47 \\
Sea surface temperature & ${ }^{\circ} \mathrm{C}$ & $* 19.35$ & $* 1.29$ & 19.32 & 2.08 \\
Sea surface salinity & $\mathrm{psu}$ & - & - & 34.28 & -0.18 \\
Rainfall & $\mathrm{mm} \mathrm{day}^{-1}$ & 2.72 & 0.14 & 2.74 & 0.21 \\
Snowfall & $\mathrm{mm} \mathrm{day}^{-1}$ & 0.17 & -0.04 & 0.14 & -0.05 \\
Total precipitation & $\mathrm{mm} \mathrm{day}^{-1}$ & 2.88 & 0.10 & 2.87 & 0.17 \\
Absorbed SW at TOA & $\mathrm{Wm}^{-2}$ & 240.57 & 5.15 & 240.34 & 4.95 \\
Outgoing SW at TOA & $\mathrm{Wm}^{-2}$ & 100.74 & -5.42 & 100.97 & -5.22 \\
Outgoing LW at TOA & $\mathrm{Wm}^{-2}$ & 238.62 & 2.55 & 239.43 & 4.92 \\
Energy imbalance at TOA & $\mathrm{Wm}^{-2}$ & 1.95 & 2.60 & 0.91 & 0.03 \\
\hline
\end{tabular}

* Sea surface temperatures prescribed in the AGCM experiments are presented for reference.

several differences between the two models concerning the scale of the increase and the spatial distribution. The ocean, in particular, does not exhibit much latitudinal dependence. The temperature increase over the oceans at low-latitudes are greater than those of the AGCM and do not differ significantly from those of the southern mid-latitudes. There is also a temperature decrease in the South Atlantic, to the west of Angola and Namibia. Temperature increases over the land masses are greater than those in the AGCM, with few exceptions, most noticeably over Greenland and western Antarctica during their respective winters. The increases are sufficiently large to counteract much of the effect of higher eleva- tion. Nonetheless, temperatures are still reduced in parts of Antarctica $\left(0^{\circ}\right.$ to $\left.80^{\circ} \mathrm{E}\right)$.

The changes in surface air temperature can be compared to those in surface albedo (Fig. 11) which are largest in parts of the polar regions. Differences between the two models in the Greenland and Barents Seas are also evident in the surface albedo. At lower latitudes, large decreases in albedo are mainly restricted to areas where shrubs and bare ground did not exist in the mid-Pliocene but are present today. 

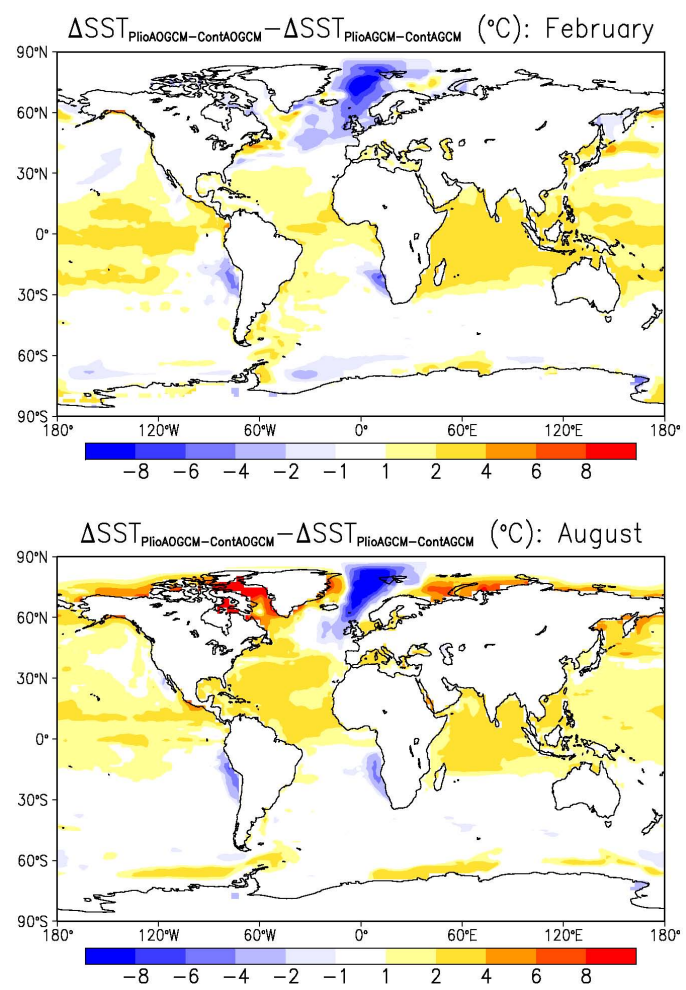

Fig. 12. Difference between the sea surface temperature anomaly in the AOGCM and that prescribed for the AGCM during February and August, i.e. (SST PlioAOGCM $^{-S_{S T}}$ ContAOGCM $_{\text {- }}$ (SST PlioAGCM $^{-S_{S T}}$ ContAGCM).

\subsection{Comparison with proxy SST reconstruction}

The ocean plays an important role in shaping the earth's climate. It is therefore important to determine where and to what degree the model simulated SSTs differ from the prescribed values. In Fig. 12, the difference between the SST anomaly in the AOGCM and that prescribed in the AGCM is shown for February and August. At low-latitudes, the prescribed SST anomalies calculated from PRISM3D data varies between the range of -1 to $1^{\circ} \mathrm{C}$ in most regions. In fact, negative anomalies (i.e. lower SST in the mid-Pliocene) dominate in the equatorial region, in particular, the Indian Ocean. Since SST mostly increases in the AOGCM (not shown), the anomalies in Fig. 12 are mostly positive.

Negative values appear off the coasts of Peru and Namibia in Fig. 12. In the former case, this can be explained by the large positive anomaly in the prescribed SST (Fig. 7 of Haywood et al., 2010) which does not appear in the AOGCM. In the latter case, this is caused by cooler water carried further north by the Benguela Current in the AOGCM. There is a large discrepancy throughout the year in the northern North Atlantic Ocean and the Nordic Seas where the increase in AOGCM SST is not as large as that suggested by the proxy data. The discrepancy is also manifested in the local surface air temperatures (Figs. 9 and 10). This raises important issues as the region exhibits the largest SST anomalies in the PRISM3D data set and is influenced by North Atlantic deep water. Large positive values appear in other parts of the northern high latitudes, for example, in the Labrador Sea, Baffin Bay, the eastern half of the Barents Sea and the neighbouring Kara Sea, especially during the summer months.

\section{Summary and conclusions}

The mid-Pliocene warm period (mPWP), 3.3-3.0 Ma, represented a time when global mean temperatures were significantly higher $\left(2-3^{\circ} \mathrm{C}\right)$ than those of today, with the most pronounced warming at high latitudes. By this period, the continents had basically attained their present day form, although future expansion of ice sheet would be associated with an estimated $25 \mathrm{~m}$ drop in sea-level. Considering the scale of both warming and $\mathrm{CO}_{2}$ increase, and the nearmodern land-sea distribution, the mPWP can be thought of as an analogue for future global warming. As such, there has been much interest in the mPWP and its relation to climatic conditions simulated for the near future with increased atmospheric $\mathrm{CO}_{2}$ concentrations. PlioMIP was established to allow systematic comparisons of mPWP simulations achieved by different groups of the paleoclimate research community, following the same protocols and using similar boundary conditions. In this paper, we explained the set-up of mPWP simulations using the MIROC4m GCM and gave a description of the model itself. Some basic results from these experiments were shown.

The experimental design for the AGCM and AOGCM follows closely the guidelines set out in PlioMIP (Haywood et al., 2010, 2011). The "preferred" set of boundary conditions are interpolated to fit the MIROC grid and a description of the experimental method is given.

Initial results show that, globally, the magnitude of warming compares well with those seen in other models and that, in the present study, surface air temperature increases more in the AOGCM. Surface air temperature increases are seen across most areas, but are particularly large at high latitudes where the surface albedo is reduced, e.g. Antarctica, Greenland and the Arctic, producing a smaller equator-to-pole temperature gradient. The zonal mean temperature at high latitudes increases by about $10^{\circ} \mathrm{C}$. The temperature increases at low- to mid-latitudes are higher and more uniformly distributed in the AOGCM compared to the AGCM, with zonal mean increases of at least $2^{\circ} \mathrm{C}$. Increases in global surface air temperature are accompanied by a reduction in snowfall. However, total precipitation increases due to enhanced rainfall, especially in the AOGCM.

Results indicate a higher sensitivity to mid-Pliocene conditions in the AOGCM, as seen in the surface air temperature and precipitation, except in the northern North Atlantic 
and Nordic Seas where the AGCM is constrained by much warmer SST. At low latitudes, the SST changes in the AOGCM can be relatively large compared to the difference between SST prescribed for the control and mid-Pliocene AGCM experiments and is more typical of the changes seen in future global climate model projections. The inability to reproduce the SST anomalies as indicated by proxy data in both the northern North Atlantic and the tropical regions may raise certain questions not only about the applicability of the proxy data, but also about the validity of the analogy between mid-Pliocene and late 21st century climate states (Dowsett et al., 2009a). However, we also have to keep in mind the simplifications made in our experimental design and consider how these may have a bearing on our results.

More detailed analyses of results from these experiments will be covered in a forthcoming paper. PlioMIP is still in its early stages and we have, at present, confined basic comparative studies to differences between the results of the MIROC4m AGCM and AOGCM, and these with previous results from other groups which used slightly different boundary conditions before the PlioMIP guidelines were set up. No doubt, the inclusion of more model-derived data and the continual availability of up-to-date proxy data will give us a better understanding of the mid-Pliocene climate, of the mechanisms which can explain its features and of its role in assessing future climate change.

Acknowledgements. The authors thank R. O'ishi for his assistance with leaf area indices and general advice on land vegetation, and the PRISM group for providing the mid-Pliocene data sets. Constructive comments from A. M. Haywood and an anonymous reviewer have helped to improve an earlier draft of this paper and are greatly appreciated. All numerical experiments were carried out on the Earth Simulator at JAMSTEC, Yokohama.

Edited by: D. Lunt

\section{References}

Amante, C. and Eakins, B. W.: ETOP1 1 Arc-Minute Global Relief Model: Procedures, Data Sources and Analysis, National Geophysical Data Center, NESDIS, NOAA, US Department of Commerce, Boulder, CO, August 2008.

Arakawa, A. and Schubert, W. H.: Interactions of cumulus cloud ensemble with the large-scale environment, Part I, J. Atmos. Sci., 31, 671-701, 1974.

Bonnefille, R., Potts, R., Chalié, F., Jolly., D., and Peyron, O.: High-resolution vegetation and climate change associated with Pliocene Australopithecus afarensis, P. Natl. Acad. Sci. USA, 101, 12125-12129, 2004.

Chandler, M. A., Rind, D., and Thompson, R.: Joint investigations of the middle Pliocene II: GISS GCM Northern Hemisphere results, Global Planet. Change, 9, 197-219, 1994.

Dowsett, H. J.: The PRISM palaeoclimate reconstruction and Pliocene sea-surface temperature, in: Deep Time Perspectives on Climate Change: Marrying the Signal from Computer Models and Biological Proxies, edited by: Williams, M., Haywood,
A. M., Gregory, F. J. and Schmidt, D. H., Micropalaeontol. Soc., Spec. Pub. Geol. Soc., London, 459-480, 2007.

Dowsett, H. J., Chandler, M. A., and Robinson, M. M.: Surface temperatures of the Mid-Pliocene North Atlantic Ocean: implications for future climate, Philos. T. R. Soc. A, 367, 109-126, 2009a.

Dowsett, H. J., Robinson, M. M., and Foley, K. M.: Pliocene threedimensional global ocean temperature reconstruction, Clim. Past, 5, 769-783, doi:10.5194/cp-5-769-2009, 2009 b.

Hasumi, H.: CCSR Ocean Component Model (COCO) Version 2.1, CCSR Report, The University of Tokyo, Japan, 13, 68 pp., 2000.

Haywood, A. M. and Valdes, P. J.: Modelling Pliocene warmth: contribution of atmosphere, oceans and cryosphere, Earth Planet. Sc. Lett., 218, 363-377, 2004.

Haywood, A. M., Valdes, P. J., and Sellwood, B. W.: Global scale palaeoclimate reconstruction of the middle Pliocene climate using the UKMO GCM: initial results, Global Planet. Change, 25, 239-256, 2000.

Haywood, A. M., Chandler, M. A., Valdes, P. J., and Salzmann, U.: Comparison of mid-Pliocene climate predictions produced by the HadAM3 and GCMAM3 General Circulation Models, Global Planet. Change, 66, 208-224, 2009.

Haywood, A. M., Dowsett, H. J., Otto-Bliesner, B., Chandler, M. A., Dolan, A. M., Hill, D. J., Lunt, D. J., Robinson, M. M., Rosenbloom, N., Salzmann, U., and Sohl, L. E.: Pliocene Model Intercomparison Project (PlioMIP): experimental design and boundary conditions (Experiment 1), Geosci. Model Dev., 3, 227-242, doi:10.5194/gmd-3-227-2010, 2010.

Haywood, A. M., Dowsett, H. J., Robinson, M. M., Stoll, D. K., Dolan, A. M., Lunt, D. J., Otto-Bliesner, B., and Chandler, M. A.: Pliocene Model Intercomparison Project (PlioMIP): experimental design and boundary conditions (Experiment 2), Geosci. Model Dev., 4, 571-577, doi:10.5194/gmd-4-571-2011, 2011.

Hill, D. J., Haywood, A. M., Hindmarsh, R. C. A., and Valdes, P. J.: Characterising ice sheets during the mid Pliocene: evidence from data and models, in: Deep Time Perspectives on Climate Change: Marrying the Signal from Computer Models and Biological Proxies, edited by: Williams, M., Haywood, A. M., Gregory, F. J. and Schmidt, D. H., Micropalaeontol. Soc., Spec. Pub. Geol. Soc., London, 517-538, 2007.

Jansen, E., Overpeck, J., Briffa, K.R., Duplessy J.-C., Joos, F., Masson-Delmotte, V., Olago, D., Otto-Bliesner, B., Peltier, W.R., Rahmstorf, S., Ramesh, R., Raynaud, D., Rind, D., Solomina, O., Villalba, R., and Zhang, D.: Palaeoclimate, in: Climate Change 2007: The Physical Science Basis. Contribution of Working Group I to the Fourth Assessment Report of the Intergovernmental Panel on Climate Change, edited by: Solomon, S., Qin, D., Manning, M., Chen, Z., Marquis, M., Averyt, K. B., Tignor, M., and Miller, H. L., Cambridge University Press, Cambridge and New York, 2007.

Jiang, D., Wang, H., Ding, Z., Lang, X., and Drange, H.: Modeling the middle Pliocene climate with a global atmospheric general circulation model, J. Geophys. Res, 110, D14107, doi:10.1029/2004JD005639, 2005.

K-1 model developers: K-1 coupled model (MIROC) description. K-1 technical report, edited by: Hasumi, H. and Emori, S., Center for Climate System Research, The University of Tokyo, Japan, 34 pp., 2004. 
Lunt, D. J., Haywood, A. M., Schmidt, G. A., Salzmann, U., Vales, P. J., and Dowsett, H. J.: Earth system sensitivity inferred from Pliocene modelling and data, Nature Geosci., 3, 60-64, 2010.

Le Treut, H. and Li, Z.-X.: Sensitivity of an atmospheric general circulation model to prescribed SST changes: feedback effects associated with the simulation of cloud optical properties, Clim. Dynam., 5, 175-187, 1991.

Levitus, S. and Boyer, T.: World Ocean Atlas Volume 4: Temperature, NOAA Atlas NESDIS 4, U.S. Government Printing Office, Washington, D.C., 117 pp., 1994.

Meehl, G. A., Stocker, T .F., Collins, W. D., Friedlingstein, P., Gaye A. T., Gregory, J. M., Kitoh, A., Knutti, R., Murphy, J. M., Noda, A., Raper, S. C. B., Watterson, I. G., Weaver, A. J., and Zhao, Z.-C.: Global Climate Projections, in: Climate Change 2007: The Physical Science Basis. Contribution of Working Group I to the Fourth Assessment Report of the Intergovernmental Panel on Climate Change, edited by: Solomon, S., Qin, D., Manning, M., Chen, Z., Marquis, M., Averyt, K. B., Tignor, M., and Miller, H. L., Cambridge University Press, Cambridge and New York, 2007.

Mellor, G. L. and Yamada, T.: Development of a turbulence closure model for geostrophic fluid problems, Rev. Geophys., 20, 851875, 1982.

Miller, J. R., Russell, G. L., and Caliri, G.: Continental-Scale River Flow in Climate Models, J. Climate, 7, 914-928, 1994.

Nakajima, T., Tsukamoto, M., Tsushima, Y., Numaguti, A., and Kimura, T.: Modelling of the radiative process in an atmospheric general circulation model, Appl. Opt. 39, 4869-4878, 2000.

Nakano, H. and Suginohara, N.: Effects of Bottom Boundary Layer Parameterization on Reproducing Deep and Bottom Waters in a World Ocean Model, J. Phys. Oceanogr., 32, 1209-1227, 2002.

National Aeronautics and Space Administration, Goddard Space Flight Center (Sellers, P. J., Meeson, B. W., Closs, J., Collatz, J., Corprew, F., Dazlich, D., Hall, F. G., Kerr, Y., Koster, R., Los, S., Mitchell, K., McManus, J., Myers, D., Sun, K.J., and Try, P.): International Satellite Land Surface Climatology Project - Initiative I data collection (ISLSCP I), NASA Distributed Active Archive Center (DAAC), available from http: //badc.nerc.ac.uk/data/islscp, 1996.

NOAA, National Geophysical Data Center, Boulder, Colorado: Data Announcement 88-MGG-02, Digital relief of the Surface of the Earth, available from http://www.ngdc.noaa.gov/mgg/global/ etopo5.html, 1998.

Noh, Y. and Kim, H.-J.: Simulations of temperature and turbulence structure of the oceanic boundary layer with the improved nearsurface process, J. Geophys. Res., 104, 15621-15634, 1999.

Numaguti, A., Takahashi, M., Nakajima, T., and Sumi, A.: Description of CCSR/NIES Atmospheric General Circulation Model, CGERs Supercomputer Monograph Report, Center for Global Environment Research, National Institute for Environmental Studies, 3, 1-48, 1997.
Ohgaito, R. and Abe-Ouchi, A.: The role of ocean thermodynamics and dynamics in Asian summer monsoon changes during the mid-Holocene, Clim. Dynam., 29, 39-50, 2007.

Pagani, M., Liu, Z., LaRiviere, J., and Ravelo, A. C.: High Earth-system climate sensitivity determined from Pliocene carbon dioxide concentrations, Nature Geosci., 3, 28-30, 2010.

Raymo, M. E., Grant, B., Horowitz, M., and Rau, G. H.: MidPliocene warmth: stronger greenhouse and stronger conveyor, Mar. Micropaleontol., 27, 313-326, 1996.

Reynolds, R.W. and Smith, T.M.: A high resolution global sea surface temperature climatology, J. Climate, 8, 1571-1583, 1995.

Robinson, M. M., Dowsett, H. J., and Chandler, M. A.: Pliocene Role in Assessing Future Climate Impacts, Eos T. Am. Geophys. Un., 89, 501-512, 2008a.

Robinson, M. M., Dowsett, H. J., Dwyer, G. S., and Lawrence, K. T.: Reevaluation of mid-Pliocene North Atlantic sea surface temperatures, Paleoceanography, 23, 1-9, 2008b.

Salzmann, U., Haywood, A. M., Lunt, D. J., Valdes, P. J., and Hill, D. J.: A new Global Biome Reconstruction and Data-Model Comparison for the middle Pliocene, Global Ecol. Biogeogr., 17, 432-447, 2008.

Schmidt, G. A.: Enhancing the relevance of palaeoclimate model/data comparisons for assessments of future climate change, J. Quaternary Sci., 25, 79-87, 2010.

Seki, O., Foster, G. L., Schmidt, D. N., Mackensen, A., Kawamura, K., and Pancost, R. D.: Alkenone and boron-based Pliocene $p \mathrm{CO}_{2}$ records, Earth Planet. Sc. Lett., 292, 201-211, 2010.

Semtner, A. J. Jr.: A model for the thermodynamic growth of sea ice in numerical investigations of climate, J. Phys. Oceanogr., 6, 379-389, 1976.

Sloan, L. C., Crowley, T. J., and Pollard, D.: Modeling of middle Pliocene climate with the NCAR GENESIS general circulation model, Mar. Micropaleontol., 27, 51-61, 1996.

Smagorinsky, J.: General circulation experiments with the primitive equations, Mon. Weather Rev., 91, 99-164, 1963.

Sohl, L. E., Chandler, M. A., Schmunk R. B., Mankoff, K., Jonas, J. A., Foley, K. M., and Dowsett, H. J.: PRISM3/GISS topographic reconstruction, U.S., Geological Survey Data Series, 419, 6 pp., 2009.

Takata, K., Watanabe, T., and Emori, S.: Development of the minimal advanced treatments of surface interaction and runoff, Global Planet. Change, 38, 209-222, 2003.

Takemura, T., Okamoto, H., Maruyama, Y., Numaguti, A., Higurashi, A., and Nakajima, T.: Global three-dimensional simulation of aerosol optical thickness distribution of various origins, J. Geophys. Res., 105, 17853-17873, 2000.

Wiscombe, W. J. and Warren, S. G.: A Model for the Spectral Albedo of Snow. I: Pure Snow, J. Atmos. Sci., 37, 2712-2733, 1980 . 